(4) To investigate the data and material already available, either taxonomic or bearing on taxonomy, with the view of correlating them with general biological principles and of establishing generalizations in comparative systematics.

(5) To press for the appointment of additional taxonomists and other biologists to the staffs of museums and other appropriate institutions.

(6) To arrange for research into the relative importance of the various factors, internal and external, operative in different groups in producing speciation and other evolutionary processes.

(7) To co-operate in the production or improvement of handbooks on British animals and plants and in the eventual publication of a British Fauna and Flora on uniform biological lines.

(8) To suggest useful lines of biological work to natural history societies and to amateurs and to assist in its co-ordination.

(9) To investigate the best methods of teaching systematics and field work in universities and schools.

(10) To stimulate discussion and to promote co-operation between workers in different branches of biology on problems of taxonomic interest.

The committees so far formed, together with the particular items of the aims of the Association with which they are concerned, are as follows:
(1) Taxonomic principles (items 1-3). Convener : Mr. J. S. L. Gilmour, Royal Botanic Gardens, Kew.

(2) Comparative systematics (item 4). Convener : Mr. J. R. Norman, British Museum (Natural History), Cromwell Road, S.W.7.

(3) Research (item 6). Convener : Dr. W. B. Turrill, Royal Botanic Gardens, Kew.

(4) Handbooks (item 7). Conveners : Captain C. Diver, 40 Pembroke Square, W.8; Mr. M. B. Crane, John Innes Horticultural Institution, Merton, S.W.19.

(5) Natural History Societies (item 8). Convener : Mr. H. W. Parker, British Museum (Natural History), Cromwell Road, S.W.7.

(6) Education (item 9). Convener : Miss B. Schafer, John Innes Horticultural Institution, Merton, S.W.19.

(7) Publications (other than handbooks). Convener: Dr. C. D. Darlington, John Innes Horticultural Institution, Merton, S.W.19.

At the close of the meeting, fifty-three biologists, in addition to the existing council and committees, gave in their names as members. Any other biologists wishing to join the Association should send their names and addresses to one of the secretaries, stating in which particular committee they are interested. For the present there is no subscription or formal method of election.

\title{
Annual Conference of the Museums Association
}

$\mathrm{T}$ HE forty-eighth annual conference of the Museums Association was held in Newcastleupon-Tyne in the week commencing July 5. The chief impression which one gained from the Conference was that museum officials are considering their problems in a new and more critical manner.

The keynote was set by Alderman Charles Squire in his presidential address. As chairman of the Leicester Museums Committee for the past twenty. seven years, he could speak with authority, and did not hesitate to criticize the general failure of municipal councils to make adequate provision for their museums. Museums and art galleries have a high place in the educational and social scheme, and are not yet getting the support which they deserve. Alderman Squire also referred to the valuable work that could be done by museums in assisting to preserve local records and the amenities of the countryside.

Another critical paper was one by Dr. W. E. Swinton (British Museum, Natural History), on "Natural History Museums and the Community". Too many small natural history museums might have as their motto "How best to kill a love of Nature", and Dr. Swinton strongly advocated the elimination of useless material and better display of the collections, so that these might inspire the visitor with a greater interest in plants, animals and rocks in their natural settings. The paper dealt with many other points of practical importance, especially the need for having as curator one who was not only a scientific worker, but also a man of action.

In the same general field there was also a valuable discussion on "Simplifying Habitat Groups", to which Mr. R. K. Perry (Liverpool), Mr. T. Russell Goddard (Newcastle), Mr. W. E. Mayes
(Leicester), and Mr. R. Wagstaffe (Stockport) contributed. It was pointed out that in a zoological exhibit it is most valuable to have an indication of the natural habitat of the birds or animals displayed, but that the elaborate group, to be found in the larger American museums, is far too expensive for the smaller English institutions. The proposals made were in the direction of suggesting habitat by branches of trees, by plants, or by other background material, and by the careful arrangement of the specimens in natural attitudes.

On the archæological side, current museum methods were again criticized, the speaker being $\mathrm{Mr}$. Ian Richmond, of Armstrong College. Mr. Richmond answered the question: "What does an archæologist expect of a museum ?" He suggested that the museum should contain a full series of local maps, especially those showing human distribution at different epochs; that one exhibit at least should display all the objects and clues that had been obtained from a single excavation; and that, wherever possible, comparative series of exhibits should be set up. He also appealed for a simple classified system of storage of all material not on exhibition.

Within the scientific field there were some important papers of a descriptive nature. Thus, Col. E. E. B. Mackintosh, director of the Science Museum, described the special exhibitions which have been developed at that Museum since 1911. It is interesting to learn that these very successful displays, which in recent years have covered such subjects as refrigeration, rubber, electro-deposition, noise and smoke abatement, electric illumination and television, take from six to twelve months to prepare, and that 
the cost of the exhibitions has varied from less than $£ 50$ to more than $£ 3,000$ (the latter cost being borne by the industry concerned).

In his account of the Hancock Museum, Mr. T. Russell Goddard explained that this institution is financed entirely by the Natural History Society of Northumberland, Durham, and Newcastle-uponTyne. It was characteristic of the scientific life of the past century that so much public service had been performed by voluntary effort; but at the present time the finances of the Society are scarcely adequate to maintain the Museum in an effective manner.

Lastly, a valuable account was given by Dr. Kathleen B. Blackburn (Armstrong College) on modern methods of pollen analysis in relation to archæological finds from peat. Mr. H. A. Hyde (National Museum of Wales, Cardiff) also dealt with this subject, and stressed its importance to the museum curator.

On the art side, Dr. John Rothenstein, director of the City Art Galleries, Sheffield, described the work which is being done in his Galleries to give schoolchildren a greater perception and understanding of contemporary art (especially in the form of household objects), while Mr. Richard Bach, of the Metro- politan Museum of Art, discussed the vigorous way in which art collections are brought to the people in New York by the Museum's "Neighbourhood Circulating Exhibitions".

In general discussions the problem of bad museums was considered more than once, and Mr. S. F. Markham (Hon. Empire Secretary, The Museums Association), after carefully defining such museums, advocated that steps should be taken to close them. Dr. C. Hay Murray, in a paper on "Museums as Department Stores", suggested that the curator should regard himself as a salesman, and study the methods of the shopkeeper. No less important, but of a more domestic nature, were papers by $\mathrm{Mr}$. Laurence Vail Coleman, director of the American Association of Museums, on "The Philosophy of a Museums Association", and by Mr. S. D. Cleveland (Manchester) on "The Future of the Museums Association". Judging from the keen interest which the Conference aroused, that future will be an active and successful one.

The next Conference of the Association (of which the headquarters are at Chaucer House, London, W.C.I) will be held at Belfast in the first week of July 1938.

\section{Flight in the Stratosphere}

A LL countries which are interested in aviation $A$ have been considering the possibility of extend. ing their activities to aircraft in the stratosphere. The greatest advantage in flying very high is that much higher speeds can be obtained for the same expenditure of power as the density of air is so much lower in the stratosphere than at ground-level. The Schneider trophy was won, for example, at a speed of 430 m.p.h. with an engine which gave 2,200 h.p. In the stratosphere, a speed of about 800 m.p.h. could be obtained for the same power. To drive the Schneider trophy winner at the latter speed near the ground would require an engine of $30,000 \mathrm{~h} . \mathrm{p}$. If stratosphere flight were possible at 600 m.p.h., then New York would be only five hours from London; so that by local time a passenger from London would arrive at New York before he started.

In vol. 7 of the Cambridge University Engineers' Association Year book recently published, Captain J. L. Pritchard points out some of the difficulties involved in flying in the stratosphere, and concludes that these will probably prevent stratosphere flight becoming a regular service, at least in the present generation. In fact, the increasing engine temperatures due to the difficulty of getting greater cooling may make regular flights in the stratosphere impossible until a new source of power is discovered.

The output of the internal combustion engine can only be maintained if the weight of oxygen it takes in per minute is maintained constant. At an altitude of 60,000 feet, the density of air is only about a tenth of what it is at ground-level. To maintain its output the engine would have to run ten times faster than at ground-level or take in ten times the volume of air.
The former alternative is impracticable so the weight of the air would have to be kept constant by supercharging. During this process, the pressure of the air is raised to about that at ground-level and the temperature by about $300^{\circ} \mathrm{F}$. As most of the heat given in the air supplied has to be dissipated, extra cooling is necessary. Despite its low temperature, the low pressure of the atmosphere at this height is a disadvantage. Supercharging requires greater weight of equipment; in fact, the higher the aeroplane the greater its requisite weight.

In 1931, Prof. Picard discovered another fact which increases the difficulties of arranging for cooling. $\mathrm{He}$ found that at a height of ten miles, the temperature outside his gondola was $-67^{\circ} \mathrm{F}$., whilst inside the temperature was $140^{\circ} \mathrm{F}$. This was due to the radiant heat absorbed by the gondola. As a method of getting over these difficulties the rocket principle has been suggested. This doubtless would work better at low temperatures than at the ones at which it has been tried. It has to be remembered also that the velocity of sound in the stratosphere is about 700 m.p.h., a speed which enthusiasts think aircraft might attain. Some engineers think that the aeroplane will have a critical speed at this speed, but it is not known how it would get through this critical speed. For this speed, the aeroplane would probably require small wings and the landing speed might have to be about 130 m.p.h.

As an offset to these disadvantages, there would be a great saving of fuel for the journey and the time would be much shorter. In the event also of an emergency landing, there would be a much greater choice of landing grounds, as it would be possible to travel 140 miles with the engine cut off by gliding from a high altitude. 